\title{
Mengukur Kepuasan Mahasiswa Terhadap Kegiatan Akademik di Pendidikan Tinggi Islam
}

\author{
Fahrurrozi $^{1}$
}

\begin{abstract}
The current research aims at understandicng student satisfaction level on academic adminitration service of Kependidikan Islam (KI) study program, Faculty of Tarbiyah IAIN Walisongo Semarang. There are 83 respondents as research sample. Research analysis method used in this current study is importanceperformance analysis from John A. Martila and John C. James. The study result shows two findings: 1) level of student satisfaction on academic administration service, when expectation conform with implementation, is $62,69 \%$; and 2) level of student satisfaction on lecture and instructor service is $66,03 \%$.
\end{abstract}

Keywords: student satisfaction, academic service, Islamic higher education

${ }^{1}$ Dosen Fakultas Tarbiyah IAIN Walisongo

\section{A. Pendahuluan}

Kependidikan Islam (KI) adalah salah jurusan di Fakultas Tarbiyah IAIN Walisongo yang cukup diminati masyarakat. Hal tersebut dapat dilihat dari perkembangan jumlah pendaftar dari tahun ketahun yang mengalami peningkatan. Melihat animo masyarakat terhadap prodi KI, maka sudah sepantasnya prodi KI melakukan analisis kepuasan mahasiswa terhadap layanan pendidikannya. Setiap kontak yang dilakukan mahasiswa ketika menjalani proses pendidikan akan meninggalkan kesan yang tidak terlupakan, baik kesan buruk maupun kesan baik. Kesan buruk akan membuat mahasiswa menceritakan hal yang buruk kepada orang lain, sebaliknya kesan yang baik akan membuat mahasiswa menceritakan hal yang baik pula kepada orang lain. Kesan yang baik akan berdampak baik kepada program studi, antara lain akan meningkatkan peminat pada prodi tersebut.
Hal ini didasarkan pada beberapa penelitian yang menyimpulkan bahwa bila konsumen yang merasa puas dapat mempengaruhi satu saja teman atau rekannya mengenai kehebatan suatu produk atau jasa yang ditawarkan suatu perusahaan dan akhirnya mendatangkan seorang konsumen atau pelanggan baru, maka nilai konsumen atau pelanggan yang pertama itu menjadi bertambah dua kali lipat. Jika hal yang sama dianalogikan dengan dunia pendidikan, hal yang sama juga akan terjadi. Apalagi di tengah persaingan yang sangat ketat antar perguruan tinggi seperti sekarang ini. Memang dalam hal ini pendidikan bukanlah organisasi yang mengejar laba, akan tetapi semakin banyak mahasiswa yang masuk ke perguruan tinggi yang bersangkutan, akan semakin meningkatkan nilai perguruan tinggi, yang pada gilirannya akan memberikan citra yang baik kepada perguruan tinggi tersebut (Alma, 2003:92).

Salah satu cara menarik minat mahasiswa untuk masuk sebuah perguruan tinggi adalah 
memberikan layanan akademik yang dapat memuaskan mahasiwa. Memberikan kepuasan layanan akademik terhadap mahasiswa prodi KI Fakultas Tarbiyah IAIN merupakan bagian yang tak terpisahkan dari seluruh kegiatan pendidikan di kampus. Mutu layanan pendidikan menjadi penentu keberhasilan meraih konsumen (mahasiswa).

Berdasarkan uraian yang telah dikemukakan di atas maka peneliti tertarik untuk melakukan penelitian tentang kepuasan mahasiswa terhadap kegiatan akademik Jurusan Kependidikan Islam Fakultas Tarbiyah IAIN Walisongo.

Adapun tujuan penelitian ini adalah: (a) untuk mengetahui tingkat kepuasan mahasiswa terhadap pelayanan akademik Jurusan Kependidikan Islam Fakultas Tarbiyah IAIN Walisongo; dan (b) untuk mengetahui strategi yang tepat untuk meningkatkan kepuasan mahasiswa terhadap layanan akademik Jurusan Kependidikan Islam Fakultas Tarbiyah IAIN Walisongo.

\section{B. Pembahasan}

\section{Kerangka Teori}

\subsection{Mutu Pendidikan}

Mutu (quality) mempunyai pengertian yang bervariasi. Sementara ini, secara garis besar ada dua pemaknaan tentang mutu, yaitu mutu sebagai suatu konsep absolut dan mutu sebagai konsep relatif (Sallis, 1993:15; Jeffries, 1993: 20).

Pertama, mutu sebagai suatu konsep absolut. Sebagai suatu konsep yang absolut, mutu sama halnya dengan sifat baik, cantik, dan benar; merupakan suatu idealisme yang tidak dapat dikompromikan. Dalam definisi yang absolut, sesuatu yang bermutu merupakan bagian dari standar yang sangat tinggi yang tidak dapat diungguli. Produk-produk yang bermutu adalah sesuatu yang dibuat dengan sempurna dan dengan biaya yang mahal. Produk-produk tersebut dapat dinilai serta membuat puas dan bangga para pemiliknya. Barang yang langka dan harga yang mahal adalah dua karakteristik penting dalam definisi ini.

Kedua, mutu sebagai suatu konsep relatif. Pengertian relatif ini memandang mutu tidak sebagai suatu atribut produk atau servis (jasa), tetapi sebagai sesuatu yang berasal dari produk atau servis tersebut. Produk atau servis mutu, dalam konsep relatif ini tidak harus mahal dan eksklusif. Produk atau servis tersebut tidak harus spesial, tapi ia harus asli, lumrah, dan familiar.

Definisi relatif tentang mutu tersebut mempunyai dua aspek. Pertama adalah memiliki spesifikasi yang dikehendaki (measuring up). Kedua adalah memenuhi kebutuhan pelanggan. Mutu bagi produsen diperoleh dengan produk atau lanyanan yang memenuhi spesifikasi sebagaimana yang telah ditetapkan sebelumnya dalam suatu bentuk atau mode yang konsisten. Mutu dapat diwujudkan oleh seorang produsen yang mempunyai sistem mutu (quality assurance system), yaitu suatu sistem yang mensyaratkan adanya produksi yang konsisten terhadap nilai standar atau spesifikasi khusus yang baik. Sebuah produk dikatakan bermutu jika secara konsisten sesuai dengan tuntutan mutu pembuatnya.

Mutu dalam persepsi produsen harus sesuai dengan persepsi pelanggan, karena pandangan produsen dan konsumen tentang mutu tidak selalu sama. Yang terjadi adalah bahwa terkadang produk dan jasa sangat baik dan bermanfaat menurut produsen, namun ditolak oleh pelanggan. Pelanggan adalah penentu akhir mutu, dan tanpa mereka institusi tidak akan eksis. Institusi pendidikan harus 
menggunakan pemaknaan ini untuk mengeksplorasi keperluan pelanggannya (Jeffries, 1993: 23). Menurut Kotler (2000: 34), nilai pelanggan adalah selisih antara jumlah nilai pelanggan dengan jumlah biaya pelanggan. Jumlah nilai pelanggan adalah sekelompok manfaat yang diharapkan dari produk dan jasa. Jumlah biaya pelanggan adalah sekelompok biaya yang digunakan dalam menilai, mendapatkan, menggunakan dan membuang produk atau jasa.

Para pelanggan - stakeholder jasa - terdiri dari bermacam-macam golongan dan perlu diidentifikasi. Jika mutu berbicara tentang memenuhi kebutuhan-kebutuhan pelanggan, maka hal penting yang perlu diperjelas adalah siapa yang akan dipuaskan kebutuhan dan keinginannya. Secara garis besar pelanggan diklasifikasikan pada dua kelompok, yaitu pelanggan eksternal dan internal lembaga pendidikan. Pelanggan eksternal adalah seperti pelajar, orangtua, dll. Sedangkan pelanggan internal terdiri dari kepala sekolah, guru, staf karyawan dan semua orang yang terlibat dalam pengelolaan pendidikan.

Secara lebih detail, pelanggan eksternal dibagi menjadi tiga bagian, yaitu pelanggan eksternal pelanggan utama (primer), pelanggan kedua (sekunder) dan pelanggan ketiga (tersier). Pelanggan utama adalah yang secara langsung menerima jasa, yaitu murid atau anak didik itu sendiri. Sementara pelanggan sekunder adalah orangtua, gubernur, sponsor pelajar yang memiliki kepentingan langsung dalam pendidikan individu khusus maupun institusi khusus. Sedangkan pelanggan tersier adalah mereka yang kurang mempunyai hubungan langsung dan bukan pelanggan utama dalam pendidikan, seperti pemilik lapangan kerja, pemerintah, dan masyarakat secara keseluruhan (Sallis, 1993: 20).

\subsection{Mutu Pelayanan dan Kepuasan Pelanggan}

Kotler memberikan empat karakteristik batasan untuk jenis-jenis pelayanan jasa, yaitu: (1) jasa berbeda berdasarkan basis peralatan (equipment based) atau basis orang (people based); (2) beberapa jenis jasa memerlukan kehadiran klien (client's presence); (3) jasa dibedakan dalam memenuhi kebutuhan perorangan (personal need) atau kebutuhan bisnis (bussiness need); dan (4) jasa dibedakan atas tujuannya, yaitu laba atau nirlaba (profit or non profit) dan berdasarkan kepemilikannya, yaitu swasta atau publik (private or public) (Kotler, 2000).

Hadisubroto menyatakan bahwa pelayanan merupakan satu bentuk kesatuan kerja dari peralatan, perlengkapan atau apa saja, dan karyawan dalam penyediaan akomodasi dari kegiatan yang diinginkan oleh orang atau publik. Uraian di atas menunjukkan bahwa lembaga pendidikan merupakan suatu lembaga pemberi jasa pada para konsumen, dalam hal ini konsumennya adalah siswa atau mahasiswa (Yermias \& Subarsono, 2004).

Kotler mengungkapkan lima faktor yang menentukan mutu pelayanan jasa meliputi: (1) tangible (bukti langsung) mencakup fasilitas fisik, perlengkapan, pegawai, dan sarana komunikasi; (2) reliability (reliabilitas), yaitu kemampuan memberikan pelayanan yang dijanjikan dengan segera, akurat, dan memuaskan; (3) responsiveness (daya tanggap), yaitu keinginan staf membantu para pelanggan dan memberikan layanan dengan tanggap; (4) assurance (jaminan), mencakup pengetahuan, kompetensi, kesopanan, dan sifat dapat dipercaya yang dimiliki staf, bebas dari bahaya, resiko, atau keragu-raguan; (5) empathy (empati), meliputi kemudahan dalam menjalin relasi, komunikasi yang baik, perhatian pribadi, dan pemahaman atas kebutuhan individu para pelanggan (Parasuraman, 1988). 
Karakteristik mutu jasa (service quality) lebih sulit untuk didefinisikan daripada mendefinisikan fisik produk, karena karakteristik mutu jasa mencakup beberapa elemen subyek yang penting. Sebab-sebab terjadi mutu produk yang jelek dan rusak tidak sama dengan sebab-sebab yang ada pada jasa. Produk sering rusak disebabkan oleh kesalahan material dan komponen yang jelek, desain produk yang rusak atau mungkin disesuaikan dengan spesifikasi. Mutu jasa yang jelek, di satu sisi, biasanya secara langsung dinisbatkan pada kelakuan atau sifat pekerja. Mereka berkelakuan dan bersikap sedemikian rupa disebabkan oleh kurangnya perhatian atau kesopanan. Ketidakacuhan dan kurangnya pelatihan atau perhatian, kerapkali merupakan alasan utama yang menyebabkan terjadinya kerusakan jasa. Karakteristik sikap dan mutu jasa harus dimunculkan dalam pikiran ketika mendiskusikan mutu pendidikan.

\section{Metode Penelitian}

Penelitian ini berupaya mendeskripsikan kepuasan mahasiswa terhadap pelayanan akademik Jurusan Kependidikan Islam (KI) Fakultas Tarbiyah IAIN Walisongo Semarang. Populasi penelitian ini adalah mahasiswa Jurusan KI Fakultas Tarbiyah IAIN Walisongo Semarang yang terdaftar sebagai mahasiswa aktif di semester 3, 5, dan 7. Adapun teknik sampling yang digunakan adalah random sampling. Teknik pengambilan data menggunakan questioner. Setelah disebarkan, terdapat 83 questioner yang kembali pada peneliti. Dengan demikian, jumlah sampel mahasiswa Jurusan KI adalah 83 responden. Jumlah sampel mahasiswa semester 3 adalah 26 responden dan umlah sampel mahasiswa semester 5 adalah 28 responden. Sedangkan jumlah sampel mahasiswa semester 7 adalah 29 responden
Adapun instrumen yang digunakan merujuk pada teori Kotler tentang faktor-faktor pelayanan yang terdiri dari: tangible (bukti langsung); reliability (reliabilitas), yaitu kemampuan memberikan pelayanan; responsiveness (daya tanggap), yaitu keinginan staf membantu para pelanggan dan memberikan layanan dengan tanggap; assurance (jaminan); dan empathy (empati).

Dalam menganalisis data penelitian ini digunakan metode deskriptif kualitatifkuantitatif. Untuk menjawab rumusan masalah mengenai seberapa tinggi kepuasan mahasiswa Jurusan KI, maka digunakan analisis tingkat kepentingan-kinerja (importance-performance analysis) dari John A. Martila dan John C. James (Supranto, 2006: 239). Analisis tersebut diarahkan pada beberapa item pertanyaan yang dikembangkan dari lima kriteria penentu kualitas jasa pelayanan. Item tersebut diwujudkan dalam dua jenis questionare, yaitu respon mahasiswa dan harapan/tingkat kepentingan. Responden memilih alternatif jawaban dengan skala likert dari angka 1 sampai 5.

Hasil penghitungan terhadap respon dan harapan mahasiswa tersebut selanjutnya ditemukan tingkat kesesuaiannya. Tingkat kesesuaian inilah yang akan menentukan urutan prioritas peningkatan faktor-faktor yang mempengaruhi kepuasan mahasiswa. Adapun rumusan yang digunakan adalah:

$$
\mathrm{Tki}=\frac{\mathbf{X i}}{\mathbf{Y i}} \times 100 \%
$$

Yang mana:

Tki $=$ Tingkat kesesuaian responden

$\mathrm{Xi}=$ Skor penilaian kinerjainstitut/fakultas

$\mathrm{Yi}_{\mathrm{i}}=$ Skor penilaian kepentingan pelanggan 
Selanjutnya sumbu mendatar $(X)$ akan diisi oleh skor tingkat kepuasan mahasiswa, sedangkan sumbu tegak (Y) akan diisi oleh skor tingkat harapan/kepentingan. Dalam penyederhanaan rumus, maka untuk setiap faktor yang mempengaruhi kepuasan mahasiswa, dirumuskan dengan:

$$
\overline{\mathrm{X}}=\frac{\sum \mathrm{Xi}}{\mathrm{n}} \quad \overline{\mathrm{Y}}=\frac{\sum \mathrm{Yi}_{\mathrm{i}}}{\mathrm{n}}
$$

Yang mana:

$\overline{\mathrm{X}}=$ Skor rata-rata tingkat pelaksanaan/kepuasan

$\overline{\mathrm{Y}}=$ Skor rata-rata tingkat kepentingan

$\mathrm{n}=$ Jumlah responden
Diagram kartesius merupakan suatu bangun yang dibagi atas empat bagian yang dibatasi oleh dua buah garis yang berpotongan tegak lurus pada titik-titik $(\overline{\bar{X}}, \overline{\bar{Y}})$ dimana $\overline{\bar{X}}$ merupakan rata-rata dari rata-rata skor tingkat pelaksanaan atau kepuasan mahasiswa. Sedangkan atribut $\overline{\bar{Y}}$ adalah rata-rata dari ratarata skor tingkat kepentingan/harapan seluruh faktor yang mempengaruhi kepuasan pelanggan. Seluruhnya ada 12 faktor atau atribut. Seluruhnya ada $\mathrm{K}$ faktor dimana $\mathrm{K}=$ 12. Rumus selanjutnya adalah:

\begin{tabular}{|c|c|c|c|c|c|c|}
\hline Faktor & Instrumen & $\begin{array}{l}\text { Penilaian } \\
\text { Pclaksanaan }\end{array}$ & $\begin{array}{l}\text { Penilaian } \\
\text { Harapan }\end{array}$ & $\overline{\mathrm{X}}$ & $\bar{Y}$ & $\begin{array}{c}\text { Tingkat } \\
\text { Kesesuaian } \\
(\%) \\
\end{array}$ \\
\hline \multirow[t]{4}{*}{$\begin{array}{l}\text { Tangible (bukti } \\
\text { langsung) }\end{array}$} & $\begin{array}{l}\text { Petunjuk dan } \\
\text { pedoman pelayanan } \\
\text { jurusan }\end{array}$ & 232 & 344 & 2,80 & 4,14 & 67,44 \\
\hline & $\begin{array}{l}\text { Kenyamanan } \\
\text { kondisi peralatan, } \\
\text { pcrlcngkapan, dan } \\
\text { ruangan jurusan }\end{array}$ & 217 & 354 & 2,61 & 4,27 & 61,30 \\
\hline & $\begin{array}{l}\text { Sarana komunikasi } \\
\text { dengan mahasiswa }\end{array}$ & 215 & 355 & 2,59 & 4,28 & 60,56 \\
\hline & $\begin{array}{l}\text { Pcrbandingan } \\
\text { jumlah pegawai- } \\
\text { mahasiswa }\end{array}$ & 208 & 339 & 2,51 & 4,08 & 61,36 \\
\hline \multirow[t]{2}{*}{$\begin{array}{l}\text { Reliability } \\
\text { (reliabilitas) }\end{array}$} & $\begin{array}{l}\text { Kemauan dan } \\
\text { antusiasme dalam } \\
\text { memberikan } \\
\text { pclayanan }\end{array}$ & 214 & 359 & 2,58 & 4,33 & 59,61 \\
\hline & $\begin{array}{l}\text { Penguasaan dan } \\
\text { kctcrampilan dalam } \\
\text { memberikan } \\
\text { pclayanan }\end{array}$ & 226 & 352 & 2,72 & 4,24 & 64,20 \\
\hline \multirow[t]{2}{*}{$\begin{array}{l}\text { Responsiveness } \\
\text { (daya tanggap) }\end{array}$} & $\begin{array}{l}\text { Kecepatan dan } \\
\text { kccckatan dalam } \\
\text { memberikan } \\
\text { pelayanan }\end{array}$ & 214 & 358 & 2,58 & 4,31 & 59,78 \\
\hline & $\begin{array}{l}\text { Sikap adil dan jujur } \\
\text { dalam memberikan } \\
\text { pelayanan }\end{array}$ & 236 & 355 & 2,84 & 4,28 & 66,48 \\
\hline $\begin{array}{l}\text { Empathy } \\
\text { (empati) }\end{array}$ & $\begin{array}{l}\text { Ketanggapan } \\
\text { terhadap masalah } \\
\text { dan keluhan } \\
\text { mahasisiwa }\end{array}$ & 209 & 351 & 2,52 & 4,23 & 59,54 \\
\hline \multirow[t]{2}{*}{$\begin{array}{l}\text { Assurance } \\
\text { (jaminan) }\end{array}$} & $\begin{array}{l}\text { Keramahan dan } \\
\text { kesopanan pegawai } \\
\text { dalam mcmbcrikan } \\
\text { pelayanan }\end{array}$ & 236 & 357 & 2,84 & 4,30 & 66,11 \\
\hline & $\begin{array}{l}\text { Kctuntasandalamm } \\
\text { emberikanpelayana } \\
\text { n }\end{array}$ & 228 & 360 & 2,75 & 4,34 & 63,33 \\
\hline Rata-rata $\overline{\bar{X}} \& \overline{\bar{Y}}$ & & & & 2,67 & 4,25 & 62,69 \\
\hline
\end{tabular}

Tabel 1:

Perhitungan Rata-Rata dari Penilaian Pelaksanaan dan Penilaian Harapan Pada Faktor-Faktor Yang Mempengaruhi Mahasiswa Jurusan KI 


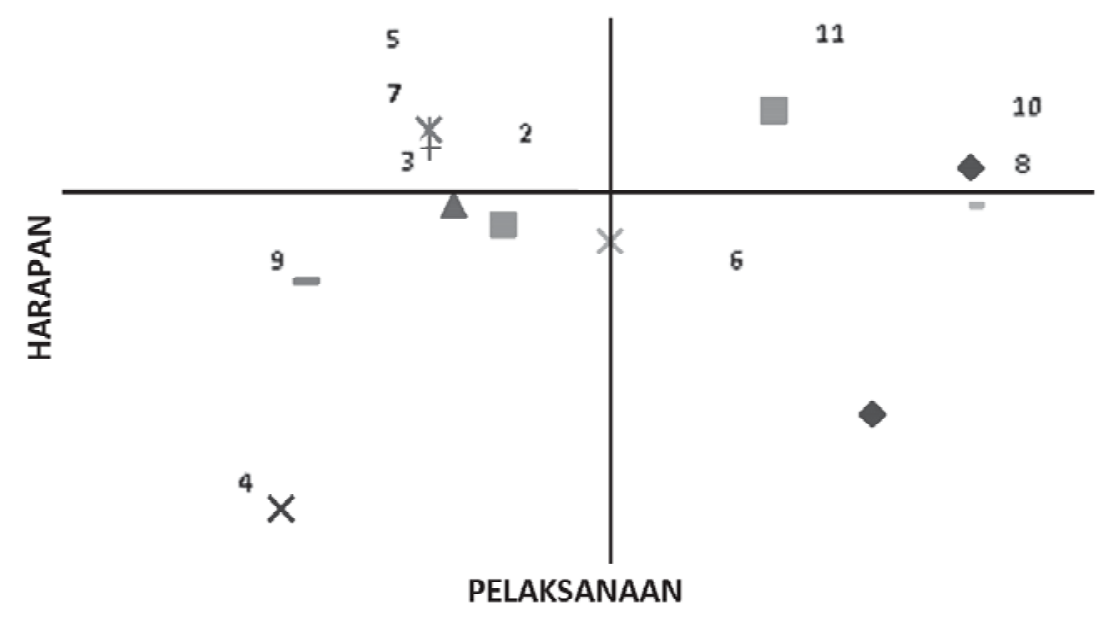

Gambar 1:

Diagram Kartesius Faktor-Faktor yang Mempengaruhi Kepuasan Mahasiswa Terhadap Layanan Akademik Jurusan KI
- Sarana komunikasi dengan mahasiswa $(=3)$ - Kemauan dan antusiasme dalam memberikan pelayanan $(=5)$

- Kecepatan dan kecekatan dalam memberikan pelayanan $(=7)$

\section{b. Kuadran B}

Kuadran ini menunjukkan bahwa faktor-faktor atau atribut yang mempengaruhi kepuasan mahasiswa yang ada dalam kuadran ini, perlu dipertahankan oleh pi-

Dalam gambar diagram di atas terlihat, bahwa letak dari unsur-unsur pelaksanaan faktor-faktor yang mempengaruhi kepuasan mahasiswa terhadap layanan administratif tingkat institut IAIN Walisongo terbagi menjadi empat bagian. Adapun interpretasi dari diagram kartesius tersebut dapat dijelaskan sebagai berikut:

\section{a. Kuadran A}

Kuadran ini menunjukkan bahwa faktorfaktor atau atribut yang mempengaruhi kepuasan mahasiswa yang ada dalam kuadran ini, perlu diprioritaskan penanganannya oleh pihak Jurusan KI. Hal itu disebabkan keberadaan faktor-faktor inilah yang dinilai sangat penting termasuk unsur-unsur jasa yang dianggap sangat penting oleh mahasiswa, sedangkan pelaksanaannya tidak memuaskan. Faktorfaktor yang termasuk dalam kuadran ini adalah:

- Kenyamanan kondisi peralatan, perlengkapan, dan ruangan jurusan (=2) hak Jurusan KI. Hal itu disebabkan secara umum pelaksanaan pelayanan telah sesuai dengan harapan mahasiswa. Faktor-faktor yang termasuk dalam kuadran B ini adalah:

- Sikap adil dan jujur dalam memberikan pelayanan $(=8)$

- Keramahan dan kesopanan pegawai dalam memberikan pelayanan $(=10)$

- Ketuntasandalammemberikan(=11)

Kuadran ini menunjukkan bahwa faktorfaktor atau atribut yang mempengaruhi kepuasan mahasiswa yang ada dalam kuadran ini dinilai kurang penting bagi mahasiswa. Faktorfaktor yang termasuk dalam kuadran $\mathrm{C}$ ini adalah:

- Perbandingan jumlah pegawai-mahasiswa $(=4)$

- Ketanggapan terhadap masalah dan keluhan mahasisiwa (=9)

\section{c. Kuadran C}




\section{d. Kuadran D}

Kuadran ini menunjukkan bahwa faktorfaktor atau atribut yang mempengaruhi kepuasan mahasiswa yang ada dalam kuadran ini, dinilai berlebihan dalam pelaksanaannya. Hal tersebut disebabkan mahasiswa menganggap tidak terlalu penting, namun pelaksanaannya memuaskan. Faktor-faktor yang termasuk dalam kuadran D ini adalah:
- Petunjuk dan pedoman pelayanan jurusan $(=1)$

- Penguasaan dan keterampilan dalam memberikan pelayanan $(=6)$

\subsection{Tingkat Kepuasan Mahasiswa Terhadap Layanan oleh Dosen Pengajar dan Strategi Peningkatannya}

Nilai rata-rata (mean) tingkat kepuasan mahasiswa terhadapa layanan akademik yang diberikan oleh

\begin{tabular}{|c|c|c|c|c|c|c|}
\hline Faktor & Instrumen & $\begin{array}{c}\text { Pcnilaian } \\
\text { Pelaksanaan }\end{array}$ & $\begin{array}{l}\text { Penilaian } \\
\text { Harapan }\end{array}$ & $\bar{x}$ & $\bar{Y}$ & $\begin{array}{c}\text { Tingkat } \\
\text { Kesesuaian } \\
(\%)\end{array}$ \\
\hline \multirow[t]{4}{*}{$\begin{array}{l}\text { Tangible (bukti } \\
\text { langsung) }\end{array}$} & $\begin{array}{l}\text { Petunjuk dan } \\
\text { pedoman } \\
\text { pembelajaran kuliah }\end{array}$ & 232 & 340 & 2,80 & 4,10 & 68,24 \\
\hline & $\begin{array}{l}\text { Kenyamanan kondisi } \\
\text { peralatan, } \\
\text { perlengkapan, dan } \\
\text { ruangan kelas }\end{array}$ & 240 & 345 & 2,89 & 4,16 & 69,57 \\
\hline & $\begin{array}{l}\text { Sarana komunikasi } \\
\text { dengan mahasiswa }\end{array}$ & 219 & 342 & 2,64 & 4,12 & 64,04 \\
\hline & $\begin{array}{l}\text { Perbandingan jumlah } \\
\text { dosen-mahasiswa }\end{array}$ & 221 & 343 & 2,66 & 4,13 & 64,43 \\
\hline \multirow[t]{2}{*}{$\begin{array}{l}\text { Reliability } \\
\text { (reliabilitas) }\end{array}$} & $\begin{array}{l}\text { Kemauan dan } \\
\text { antusiasme dalam } \\
\text { memberikan } \\
\text { bimbingan }\end{array}$ & 225 & 355 & 2,71 & 4,28 & 63,38 \\
\hline & $\begin{array}{l}\text { Penguasaan dan } \\
\text { keterampilan dalam } \\
\text { memberikan } \\
\text { pelayanan }\end{array}$ & 241 & 352 & 2,90 & 4,24 & 68,47 \\
\hline \multirow[t]{2}{*}{$\begin{array}{l}\text { Responsiveness } \\
\text { (daya tanggap) }\end{array}$} & $\begin{array}{l}\text { Kecepatan dan } \\
\text { keckatan dalam } \\
\text { memberikan } \\
\text { perkuliahan }\end{array}$ & 232 & 343 & 2,80 & 4,13 & 67,64 \\
\hline & $\begin{array}{l}\text { Sikap adil dan jujur } \\
\text { dalam pembelajaran }\end{array}$ & 237 & 350 & 2,86 & 4,22 & 67,71 \\
\hline $\begin{array}{l}\text { Empathy } \\
\text { (empati) }\end{array}$ & $\begin{array}{l}\text { Ketanggapan } \\
\text { terhadap masalah dan } \\
\text { keluhan mahasisiwa }\end{array}$ & 210 & 350 & 2,53 & 4,22 & 60,00 \\
\hline \multirow[t]{2}{*}{$\begin{array}{l}\text { Assurance } \\
\text { (jaminan) }\end{array}$} & $\begin{array}{l}\text { Keramahan dan } \\
\text { kesopanant dalam } \\
\text { memberikan } \\
\text { bimbingan }\end{array}$ & 240 & 360 & 2,89 & 4,34 & 66,67 \\
\hline & $\begin{array}{l}\text { Ketuntasandalamme } \\
\text { mberikanperkuliahan }\end{array}$ & 236 & 356 & 2,84 & 4,29 & 66,29 \\
\hline Rata-rata $\overline{\bar{X}} \& \overline{\bar{Y}}$ & & & & 2,77 & 4,20 & 66,03 \\
\hline
\end{tabular}

Tabel 2:

Perhitungan Rata-Rata dari Penilaian Pelaksanaan dan Penilaian Harapan Pada Faktor-Faktor Yang Mempengaruhi Mahasiswa Jurusan KI dosen pengajar, dapat dijelaskan sebagai berikut:

Sebagaimana diungkap dalam tabel di atas, diketahui bahwa nilai rata-rata praktik layanan akademik yang diberikan oleh Dosen KI adalah 2,77, sedangkan nilai rata-rata harapan mahasiswa terhadap layanan akademik dosen adalah 4,20. Adapun nilai tingkat kese$\mathrm{su}$ a i a n $\mathrm{n}$ a adalah 66,03. Tingkat kesesuaian tersebut menunjukkan bahwa mahasiswa merasa 
cukup puas terhadap layanan akademik yang diberikan oleh Dosen KI. Oleh karena itu, pihak dosen Jurusan KI dituntut melakukan perbaikan layanan dengan prioritas sebagaimana digambarkan dalam diagram kartesius berikut:

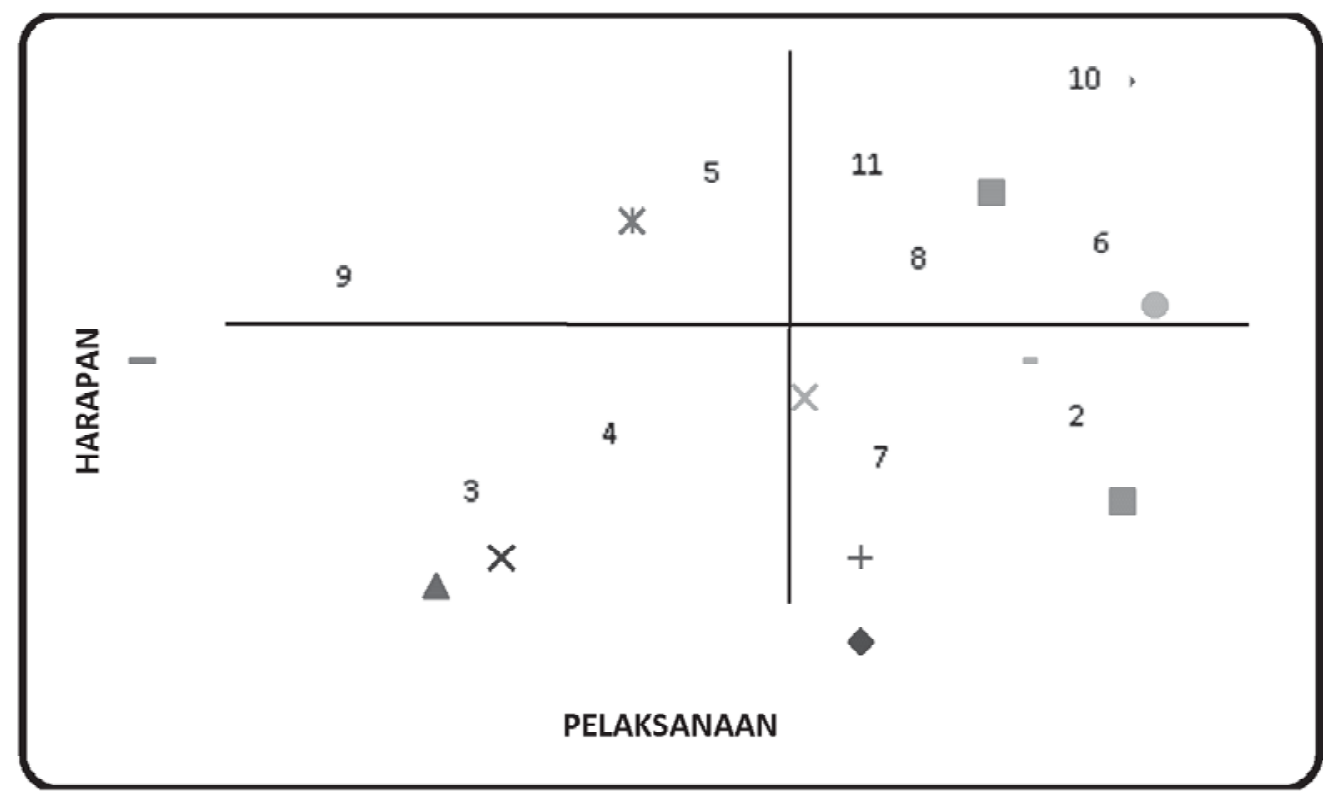

Gambar 2:

Diagram Kartesius Faktor-Faktor yang Mempengaruhi Kepuasan Mahasiswa Terhadap Layanan Akademik Dosen
Dalam gambar diagram di atas terlihat, bahwa letak dari unsur-unsur pelaksanaan faktor-faktor yang mempengaruhi kepuasan mahasiswa terhadap layanan akademik dosen Jurusan KI terbagi menjadi empat bagian. Adapun interpretasi dari diagram kartesius tersebut dapat dijelaskan sebagai berikut:

a. Kuadran A

Kuadran ini menunjukkan bahwa faktorfaktor atau atribut yang mempengaruhi kepuasan mahasiswa yang ada dalam kuadran ini, perlu diprioritaskan penanganannya oleh dosen Jurusan KI. Hal itu disebabkan keberadaan faktor-faktor inilah yang dinilai sangat penting termasuk unsur-unsur jasa yang dianggap sangat penting oleh mahasiswa, sedangkan pelaksanaannya tidak memuaskan. Faktorfaktor yang termasuk dalam kuadran ini adalah:

- Kemauan dan antusiasme dalam memberikan bimbingan (=5)

- Ketanggapan terhadap masalah dan keluhan mahasisiwa (=9) b. Kuadran B

Kuadran ini menunjukkan bahwa faktorfaktor atau atribut yang mempengaruhi kepuasan mahasiswa yang ada dalam kuadran ini, perlu dipertahankan oleh dosen Jurusan KI. Hal itu disebabkan secara umum pelaksanaan pelayanan telah sesuai dengan harapan mahasiswa. Faktor-faktor yang termasuk dalam kuadran B ini adalah:

- Penguasaan dan keterampilan dalam memberikan pelayanan $(=6)$

- Sikap adil dan jujur dalam pembelajaran $(=8)$

- Keramahan dan kesopanan dalam memberikan bimbingan (=10)

- Ketuntasan dalam memberikan perkuliahan (=11).

\section{c. Kuadran C}

Kuadran ini menunjukkan bahwa faktorfaktor atau atribut yang mempengaruhi kepuasan mahasiswa yang ada dalam kuadran ini, dinilai kurang penting bagi mahasiswa. Faktor-faktor yang termasuk dalam kuadran C ini adalah: 
- Sarana komunikasi dengan mahasiswa $(=3)$

- Perbandingan jumlah dosenmahasiswa $(=4)$

d. Kuadran D

Kuadran ini menunjukkan bahwa faktorfaktor atau atribut yang mempengaruhi kepuasan mahasiswa yang ada dalam kuadran ini, dinilai berlebihan dalam pelaksanaannya. Hal tersebut disebabkan mahasiswa menganggap tidak terlalu penting, namun pelaksanaannya memuaskan. Faktor-faktor yang termasuk dalam kuadran D ini adalah:

- Petunjuk dan pedoman pembelajaran kuliah (=1)

- Kenyamanan kondisi peralatan, perlengkapan, dan ruangan kelas (=2)

- Kecepatan dan kecekatan dalam memberikan perkuliahan $(=7)$

\section{Kesimpulan}

Berdasarkan temuan-temuan di atas, maka dapat dikemukakan saran yang kiranya bermanfaat bagi Jurusan KI, yaitu: hendaknya lebih memperhatikan kenyamanan kondisi peralatan, perlengkapan, dan ruangan jurusan dan kelas; hendaknya menyediakan sarana komunikasi yang efektif; hendaknya meningkatkan antusiasme dalam memberikan layanan dan bimbingan; hendaknya meningkatkan kecepatan dan kecekatan dalam memberikan layanan pada mahasiswa; meningkatkan perhatian terhadap masalah dan keluhan mahasiswa.

\section{Daftar Pustaka}

Alma, Buchori. 2003. Pemasaran Strategik Jasa Pendidikan. Bandung: Alfabeta.

Evans, James R. 2005. The Management and Control of Quality. Singapore: SouthWestern.

Jeffries, David R. 1993. Training for Total Quality Management. London: Kogan Page.

Kotler, Philip. 2000. Marketing Management. Millennium Edition. New Jersey: Prentice Hall Inc.

Lunenburg, Fred C. 2004. Educational Administration. New York: Thomson Wadsworth.

Parasuraman, A., Zeithmal, V.A. \& Berry, L.L. 1988. SERVQUAL: A Multiple-Item Scale for Measuring Consumer Perceptions of Service Quality. Journal of Retailing, 64 (Spring), pp.12-40.

Sallis, Edward. 1993. Total Quality Management in Education. London: Kogan Page..

Jeffries, David R. 1993. Training for Total Quality Management. London: Kogan Page.

Supranto. 2006. Pengukuran Tingkat Kepuasan Pelanggan. Jakarta: Rineka Cipta.

Yermias, Kimsean, Y. T. K., dan Ag. Subarsono. 2004. Analisis Kinerja Publik pada Pelayanan Terpadu Satu Atap Kota Yogyakarta. Jurnal Sosiosains, Volume 17, Nomor 3, Juli 2004. Pascasarjana Fisipol UGM Yogyakarta. 